the cultivation of original experimental research show that it is a national necessity, and naturally suggests the idea, can we not by a greater degree of encouragement of such research still further increase employment for working men, and still further elevate their intellectual condition?

At the present time there is in this country no recognised payment for the labours of scientific discovery, and no provision for the support of men who investigate science; any person is at liberty to take the published results of scientific men from the Transactions of the Royal Society, the Chemical Society, and other learned bodies, and employ them as the basis of inventions and patents, without the slightest payment, notwithstanding these results have been obtained at an immense cost of study, time, and labour, and a large amount of money. I do not mean by these remarks to conclude that scientific discoveries should not, on publication, become at once public property, but that some means of support should be provided for the men who make them, and thus the development of employment for workmen be increased.

Experimental scientific research, in the stricter sense of the words, is a comparatively modern thing, and though it has existed in a more limited degree during many centuries, it can only freely exist and thrive in civilised countries. Even at the present time, in consequence of the peculiar nature of the occupation, its hopelessness as a source of emolument to the investigator, the great skill and extreme self-denial required, and frequently danger incurred in its pursuit, and the consequent great difficulty of achieving success in it, scarcely one person in one million of the population of England is exclusively devoted to it, although a much greater proportion occupy a small amount of their time in its advancement.

The extension of physical and chemical knowledge by means of experiments and observations is national work: it benefits the nation, but does not pay the investigator. The various scientific men who discovered the chief facts and principles of science upon which steam-engines, electric telegraphs, and all the modern applications of science are based, received no remuneration for their researches. The results of purely scientific investigations are generally unsaleable, because, instead of benefiting a single manufacturer only, they benefit the whole nation; the nation, therefore, being the gainer, should pay and provide for those who make such researches. And when we consider that in this country upwards of 576 millions of pounds have been expended in the construction of railways alone, and immense sums upon electric telegraphs, which would never have been expended but for such labours, and nearly all of which have given employment to numberless workmen, it is evident that the magnitude and national character of the resuits would fully justify national encouragement of original experimental research.

The more abstract an experimental investigation is, the more important and widely diffused are its practical results. Who would have thought, when Oersted in his original abstract research in electro-magnetism first made a magnetized needle move by the influence of an electric current, that his labours would lead to the expenditure of many millions of pounds in the laying of telegraphs all over the earth, and the employment of many thousands of persons in their construction, maintenance, and use?
And who can tell how many similar important discoveries have been lost to the nation, and how much of the present deficiency of employment for workmen has arisen, in consequence of experimental scientific investigators not having been paid for their labours?

At present, original experimental researches are generally made by teachers of science who expend a portion of their incomes in making experiments and observations; but the very limited means of such men is a serious loss to the nation by greatly retarding the progress of discovery, and consequently also of improvements in manufactures. Many of the experiments, also, necessary for the development of new discoveries are beyond the means of such persons at present, and cannot be made without the command of greater wealth.

If England is to keep pace with the progress of foreign intellect and of foreign manufacture, and keep her workmen fully employed, there must not only be a general diffusion of scientific knowledge throughout this country, but there must also be national encouragement of original scientific investigation.

Has it been wise in our Governments thus to overlook a great source of the nation's wealth, to disregard a most important means of national economy, to neglect the great fountain-head of industry? Shall we allow foreigners to supplant us in manufactures, and shall our fellow-men continue to be driven to emigration by want of employment? or shall we develope for them new sources of labour by means of original experimental research ? It needs only to bring the subject fairly and effectually before the attention of our present enlightened and progressive Government, to ensure its careful and early consideration.

The neglect of original experimental science in this country by our Governments has long been noticed by scientific men and others, and a suggestion has been made to the British Association by Lieut.-Colonel Strange, to found "National Colleges of Original Research," in which science should be investigated, but not taught. This would be one way of supplying the want; the funds for supporting such colleges might with propriety be obtained from the fees paid for patents, because patents are in many cases based upon the published results of original experimental researches; other ways of supplying the want might also be indicated.

GEORGE GORE.

\section{OUR DOMESTIC FIRE-PLACES}

Our Domestic Fire-places. By Frederick Edwards, jun. A new edition, \&c. (London : Longmans, Green, and Co. 1870. )

THIS book, although bearing considerable traces of having for its object the advocacy of a particular manufactured article-nevertheless shows the author to have so much mastery over his subject as to justify its publication; and if the work be considered merely as the contribution of a highly qualified producer, the duty of the reviewer would be almost entirely to commend it ; but if it is proposed as a complete and unbiassed treatise on the domestic fire-place he finds a good deal of reason to dissent. 
After a somewhat diffuse essay on the hearth of the ancients-in which, by the way, the theory is too easily adopted that the Romans were entirely ignorant of the chimney-we come to the methods of our ancestors. Why the cosy folding screen must henceforth be given up, and why, in speaking of the introduction of the smoke-jack, the past services of the turnspit dog are entirely ignored, may be asked in passing.

Page $r 7$ introduces some interesting particulars of the frist use of coal, and page 30 a well-merited eulogium on the labours of Count Rumford in the improvement of firegrates, and we now approach the pith of the whole matter, namely-how to burn our coal so as to get the maximum of heat with the minimum of smoke and soot. (pp. 44 et. seg.) Here the author, having one excellent contrivance to recommend (namely, Dr. Arnott's smoke-consuming grate), has allowed himself to be unfair to other inventors whose grates for certain purposes are preferable. Of this class perhaps the most conspicuous example is the manner in which Taylor's stove, manufactured by the Coalbrookdale Co., is treated in the work before us. It is indeed mentioned (page $5 \mathrm{l}$ ) as an ingenious contrivance but full of deficiencies in practice, and as one which "now appears to have become forgotten." As respects its deficiencies, several instances are well known to us in which this grate of Mr. Taylor's has given the greatest satisfaction. No unsightly contrivances-no troublesome machinery-a bright fire-the whole apartment pervaded by the fresh warm air brought from an external source to the back of the stove, and emitted from the radiating tiles-the chimney-sweeper's visits for years dispensed with-such are some of its characteristics; and as to its "having become forgotten," assurance has been received from good authority that the demand for these grates is well kept up.

There are also several stoves which in a work like the present should have been noticed, e.g. Wright's, Woodcock's, Rosser's, and especially Galton's.

At page 54 the author discusses the recommendations of the committee appointed by the Board of Health, and gives some valuable comments upon them, and then proceeds to consider the question of the Stove of the Future, in its materials and management. Nothing has been more clearly established than the superiority of fire-brick over iron for the "fire-pot," or actual inclosure of the fuel. But the benefit of this discovery has, as yet, only reached the upper and middle classes of society, "but," says the author, p. 66, "in small houses and in the apartments occupied by skilled and unskilled workmen, the use of fire-brick is unknown, so that those who most require to use economical grates are those who are most ill provided. The working classes have either the most trumpery contrivances that Thames-street can furnish, and which are put into the fire-place at the smallest possible expense for labour and materials; or they use, in streets which have become gradually deserted by the classes which once lived in them, the badly arranged fire-places of thirty or fifty years ago."

We hope that these valuable observations will not be lost. Such fire-places as Pierce's Cottage Grate, described p. 39, are scarcely more expensive than the cheap and trumpery contrivances referred to, and if the proper arrangement of the chimney throat could also be secured in all newly constructed houses for the working- classes, the effect would be soon apparent both in favour of their health and of their pockets.

This improvement of the chimney throat is described by the author p. 73, and consists in contracting the flue to its ordinary capacity at once at the top of the fire-place opening, instead of the more common practice of gathering it in by degrees.

In p. 85 , the plan of having a single main chimneyshaft for all fire-places which are situated in the same part of the house is advocated. It is not evident, from the text, whether the author is aware that this plan has been carried out, in several instances, in different parts of the country. It is a subject, certainly, which deserves more attention than it has yet received.

In the last chapter (p. 90), the general warming of halls, corridors, \&c., is considered. It may be mentioned in connection with the Russian and Swedish method referred to, that the Germans, who have hitherto adopted generally the same plan, are beginning to place the firefront of the stove in the apartment that is to be warmed by it, instead of in the corridor, with the stove surface only in the apartment, and, as may be supposed, with a manifest improvement in the ventilation.

This chapter is well worth attention: exception must, however, be taken to the way in which Gurney's stove is mentioned, p. 108. "The prestige attaching to the name of its producer," may, indeed, have not been without its use in obtaining for these stoves their first trial, but would hardly have been sufficient, apart from their intrinsic good qualities, to have obtained for them the wide reception both at home and abroad which they have had; or to have created the almost invariable satisfaction with which their use has been attended.

The book is a useful contribution to the literature of the subject, and well illustrated by engravings. F.C.P.

\section{OUR BOOK SHELF}

The Mammalia of Massachusetts. By J. A. Allen. (Trubner \& Co.)

FROM this carefully drawn-up report we learn that there are sixty-five mammals at present indigenous to this American State. The common ones, with a few exceptions-as the mink (Putorius lutreolus), weazel ( $P$. ermineus), and skunk (Meflutis mephitica), among the carnivores; Vespertilio subulatus and Lasiurus noveboracensis among the bats-belong to the families of the rodents, the squirrels, mice, and hares, and to the Balcenidce and Delphinidse, which latter are of course marine. The panther, moose, reindeer, elk, and beaver have comparatively recently become extinct. A notice is appended to the work by Prof. Agassiz, earnestly requesting friends to forward to him males, females, and young of almost any of the European mammals. Books on mammalia would be equally valued, and in exchange he offers on the part of the museum at Cambridge, U.S., representatives of the North American fauna and American books.

Effects of Climate and Soil upon Plants.-Die Abhängig. keit der Pfanzengestalt von Klima und Boden. Von A. Kerner. Pp. 48. (Innsbruck, 1869. London : Williams and Norgate.)

THIS pamphlet is of greater importance than would be indicated by its mere size, as a contribution towards an investigation of the causes which lead to the diversities of floras, and hence towards a knowledge of the laws on which depends the great problem of the origin of species. M. Kerner has made a special study of the flora of the 